\title{
Impact of Training on Non-Managerial Employee Performance in Star Rated Hotel Industry in Matale District
}

\author{
G.M.D.C.Disanayaka, W.W.A.N.Sujeewa \\ Department of Business Management, Faculty of Management studies, Rajarata University of Sri Lanka \\ DOI: 10.29322/IJSRP.10.03.2020.p9933 \\ http://dx.doi.org/10.29322/IJSRP.10.03.2020.p9933
}

\begin{abstract}
Training is regarded as an important concept that leaders have to learn for greater performance of employees of any organization. The purpose of this study was to examine the impact of training on non-managerial employees' performance in hotel industry in Matale District. Therefore, this study could make important contribution to management field. The research model conceptualized a positive impact of independent variables (competencies, individual characteristic, trainers and work environment) on the dependent variable (employee performance). A total of 154 non managerial employees were selected from three hotels in Matale district. proportionate stratified random sampling method were used for selecting sample and included the sample 50\% of employee in each level. A structured questionnaire was used to measure the dependent and independent variable and analyzed using the descriptive analysis, correlation analysis and regression analysis. Correlation analysis results revealed that there is positive relationship between independent variable (Competency, Individual characteristic, Trainers and work environment) and employee performance. The results of regression analysis, indicated there was positive and significant impact of competency on employee performance, significant positive impact of individual characteristic on employee performance, positive significant impact of trainers on employee performance and positive significant impact of work environment on employee performance. Furthermore, $\mathrm{R}^{2}$ value indicated that $39 \%$ variance of employee performance was explained by independents variables (Competencies, individual characteristic, trainers and work environment).
\end{abstract}

Key Words- Employee Performance, Training,

\section{INTRODUCTION}

Employees are one of major resource that providing rare, inimitable value in order to gaining the competitive advantage for the organization. Thus, every organizations focus on enhancing and carrying better employee performance for ensuring the sustainable survival of the organization. Poor performance management led to the high turnover lower productivity and higher cost. (Omran, 2016) Duggan (2017) stated that after the revamps of performance management it has cut down voluntary employee turnover by $30 \%$. It is clear that poor performance management can occur less motivation, turnover etc. Lack of ability to perform a given task for the employees caused to increase the level of turnover of the organizations. Further Sanyal and Hisam (2015) proved the above statement by clarifying less of capable employees are prefer to leave the job as employees are lack of ability to understand and have no proper idea how to perform the given task. Hijr and Haleem (2017) Pointed out that employee performance of the employees in Steel Factory in Saudi Arabia was in lower level due to the lack of knowledgeable workers. Also lower level performance led to lower productivity and high cost of the organization. Omran (2016) indicated that the construction industry in Libya is suffering from number of issues due to the lack of employee performance. Sanyal and Hisam (2015) Stated that there was major issue with the performance of the employees in the educational industry. Many of employees are with lack of competency and many of staff members don't have requisite knowledge and skill in the educational system. Ameeq and Hanif (2013) pointed out that even though there was growing hotel industry in Pakistan the performance is falling down. Hassan, Mugambi and Waiganjo (2015) indicated that hotel industry in Kenya showing declining results even there were highly increasing industry for the hotels. The author further stated that pay attention for the enhancing employee performance could be effective in relevant to overcome the obstacles. Zhang (2016) stated up to considerable time period the market growth rate of the United Kingdom had a favorable manner, with the global slum in $2008-2009$ the growth rate in the hotel industry had no considerable improvements. Even in the Sri Lanka the employee performance in hotel industry faced many of issues in employee performance. Through the interviewed carried out by selected hotel managers shared information regarding employee performance problems. There were three managers for the interview from Matale district. One of manager shared experience that some employees are dealing with visitors in aggressive manner and many of complains arise from the visitors for the management due to the unpleasant behavior of the employees towards the visitors. Furthermore, out of seven employees three of employees were resigned in the hotels concluding the reason for leaving the hotel due to inability and lack of knowledge about performing job task. Daily Mirror (2015) mentioned Sri Lanka Was the sixth largest forex earner to the country at one time and but now it has declined to the third place preceded by only apparel industry and worker remittance. The article published by the Daily Mirror (2018) has reported that even Sri Lanka has reported high economic growth rate comparing with other south Asian countries, per capita income is relatively low. Therefore, it has 
indicated that tourism and hospitality sector as one of major industry to drive Sri Lanka in an efficient way as Tourism sector is the fastest growing sector with annual economic growth rate 25\% - 30\% (Daily Mirror 2018) But still there are some major problem related to develop the tourism sector due to Labor shortage. (Daily Mirror 2018) which means employees who has no sufficient skill and abilities to perform the job well. Daily News (2010) reported that Lionel Wijesiri further mentioned that non market driven strategy as a key issue in the tourism industry which means unable to enhance the market value of the tourism industry. Daily Mirror (2017) reported that there is lack of professionally efficient work force and more consideration need to give for enhancing employee performance in order to developing the tourism industry in Sri Lanka. As a one of major sector focusing the uplifting economy of Sri Lanka more attention on enhancing employee performance is really essential. Hence within Sri Lankan context it is really important to focus on enhancing employee performance for the Organization development and ultimately country development

\section{Problem Statement}

Identifying the importance of training in recent years has influenced by the organizations where investment in employee development is considerably emphasized. (Hijr \& Haleem, 2017) Training is need to ensure that the staff is technically and socially competent and capable of career development into specialist management positions. Hence, continuous staff development, training fulfils are important process. (Hijr \& Haleem, 2017) Even though strong assumptions that work place training influenced employee out comes such as motivation, commitment, job knowledge, functional skill there is limited Studies in field settings addressing the issues empirically (Dysvik \& Kuvaas, 2008) Also Burgard Gorlitz (2011) argued that non-monetary returns to training are less often examined in the empirical literature. Hence, above statements prove that how important is it to study the impact on training on competency, individual characteristic, trainers and work environment on employee performance. Training is not important only for particular organization, training is equally important to all the organizations in the economy. The hotel industry, one of important industry in the economy plays very significant role in the overall economic development, foreign exchange earner and development of the country. The researcher believes that the greater development of the hotel industry is the greater development of the country. A lot of researches has already been done on impact of training and development on employee performance (Ameeq \& Hanif, 2013;Omran, 2016) But most of those research is based on banking sector or public sector. A study in hotel industry examine impact of training on employee performance in Sri Lankan context is a new thing. For this study the dimensions used in conceptual frame work is non-monetary factors including competency, individual characteristic, trainers and work environment. Hence, above statement also proves that a study regarding such dimensions are really importance now a day. This study will be immensely relevant not only for academic purpose, but also for the view of corporate implementation. Competence in employee's qualities which lead to the better performance will analyze.

Therefore, here contradictions on training and its impact on non-managerial employees' job performance in hotel industry in Matale district lead to the identification of a research problem that is worth to study. The problem statement addressed in the present study;

Do competency, individual characteristic, trainers and work environment contribute to non-managerial employees' job performance in hotel industry in Matale district?

\section{LITERATURE REVIEW}

\subsection{Employee Performance}

Afsana, Afrin , and Tarannum (2016) Defined employee performance as the attainment of specific tasks through the effort apply by employees of an organization. The most valuable asset in an organization is the workforce.. There are number of dimensions that can be used to measure employee performance either in organization context or employee context. According Ahuja (2006) productivity, efficiency, effectiveness, quality and profitability of organization are dimensions that can be taken to measure the performance. The working quality can be carried out through the employee maximum commitment to perform task, employee positive attitudes to meeting organization's expectation being understand personal performance objectives. (Zhangpeidi, 2016) According Aguinis (2006) dimension of performance explained as task dimension of performance and contextual dimensions of performance. Task dimension of employee performance include all activities that use or allow to complete the task of the job. Contextual dimension of performance is including all behaviors that make an employee act responsibility and helping to achieve organizational goals. Murphy (1989) stated that task performance, contextual performance and downtime behavior are dimensions of employee performance. Allworth and Hesketh (1999) pointed out that contextual performance, task performance and adoptive performance as dimensions of employee performance. Task performance, Contextual performance, Adaptive performance, counterproductive behavior as dimensions of employee performance. (Koopmans, Bernaards, Hildebrandt Schaufeli, Vet \& Beek, 2011) Sinclair and Tucker (2006) indicated that contextual performance, task performance and adaptive performance has significant impact on employee performance. Kappagoda (2018) indicated that task performance and contextual performance of employees are very important for the organizational performance. Different researchers have identified various dimensions of employee performance. But for this study the researcher used task performance, contextual performance and adoptive performance (Koopmans, et al., 2011; Kappagoda, 2018; Sinclair \& Tucker, 2006; Allworth \& Hesketh, 1999) as the dimensions of employee performance

\subsection{Training}


Noe (2010) defined training as planed effort done by a company to facilitate employees' learning of knowledge, skill, behavior (competencies) related to the job, that are important to successful employee performance.. Motlokoa et al (2018) stated that training helped to sharpen the employees Knowledge, skill, capabilities in order to have better employee performance. Tahir, Yousafzi and Hashim (2014) indicated that training enhance employees' knowledge, skill, competency. Training helped to get skilled and capable employees to the organization than untrained employees. Orman (2016) stated that curricular of the training program, administrative and supervisory service, Ali (2011) indicated that the learner, learning process, content, learning environment are significant factors for successful learning while Kaur, Shiram and Kavichardran (2011) argued that people, structure, environment and resources are important for success training. Participants, trainers, training material, work environment has significant impact on effectiveness of the training according (Sharif \& Bhauiyan, 2015) Work environment characteristics, participant's characteristics, training design are effect to the training. Accordiing Nassazi (2013) most of benefits derived from training when training is planned, which means organization, trainers and trainees are in adherence need to prepared. Thus it proved that competency (Tahir., et al 2014; Driskell, 2011; Punia \& Kant, 2013; Motlokoa \& Sekantsi, 2018) trainees' characteristics (Noe, 1986; Piezzi, 2002; Driskell, 2011; Ali, 2011; Shiram \& Kavichardran 2011) trainers (Orman, 2016; Sharif \& Bhauiyan, 2015; Nassazi, 2013) work environment (Yaqoot et al., 2017; Ali, 2011; Shiram \& Kavichardran, 2011; Sharif \& Bhauiyan, 2015; Tonhauser \& Buker, 2016; Yaqoot et al., 2017) are important factors that affect to the training.

According parsimony concept simplicity is much important for implementing solutions for the problems in complex research rather than considering large number of factors. Having unmanageable factors are out of manager's control to change. Thus it is better to have limited or manageable number of factors that mangers cab be easily make implementation for better solution for particular problem. Hence for the study also it has selected number of factors that affect to the training in order to have better employee performance. competencies, trainees' characteristics, trainers, and work environment are the factors that used for the study (Sekaran, 2010)

\subsection{Relationship between Training and Employee performance}

Angela (2014) stated that training effects the performance of employee. The findings indicated that training enhance employee performance. Javeed, Ahmad and Iqbal (2014) indicated relationship between training and its impact on employee performance in telecommunication sector by using 150 employees for research.. The research findings of the Boateng (2011) showed that training has a significant impact on employee productivity. . Mohamud (2014) highlighted that training affect employee performance in public sector in Kenya.

\subsubsection{Relationship Between Competencies and Employee Performance}

Nyokabi (2014) stated that training play significant role in developing existing and new employees' competencies for effective performance. The findings highlighted that training provide significant impact on acquiring knowledge, skill, attitudes (competencies) which assist to improve employee performance by applying relevant training course based on organizational objectives. Tanveer (2015) stated the impact of training on employee performance in banking sector. The findings pointed out that training had positive impact on employee job knowledge, Skill, quality of work which are directly linked with employee performance.

\subsubsection{Relationship Between Individual Characteristics and Employee Performance}

According Gitongu, Kingi, and Uzel (2016) indicated that there was moderate and positive significant correlation between individual characteristics and employee performance. Cheong and Desa (2011) pointed out that positive influence of individual characteristic on employee performance. According Rehman, Ullah, and Haq (2015) employee character abilities including interpersonal ability, emotional skill and physical abilities have significant influence on employee performance.

\subsubsection{Relationship Between Trainers and Employee Performance.}

Driskell (2011) indicated that training content and trainers have significant impact in order to have better employee performance. Salah (2016) indicated that there is positive impact of training and trainers in order to improve employee performance. Manjula (2017) stated that expertise trainers have impact on effective training in order to have better employee performance.

\subsubsection{Relationship Between Work Environment and Employee Performance}

Zhang (2016) indicated the factors affecting employee performance in the UK hotels. The results pointed out that the greater working environment within organization helped employee to deliver higher quality service and better employee performance. (Gittell, Seidner \& Wimbush, 2010) According Munisamy (2013) stated that work environment has strong positive relationship with job performance. Less encouragement from the management, uncomfortable working environment decrease employee performance and findings pointed out that working environment has significant impact on job performance.

Thus based on the research findings following hypothesis were developed for the study.

H: There is Positive impact of training on non managerial employee performance in hotel industry. H1:There is a positive and significant impact of competency on non-managerial employee performance in hotel industry in Matale district.

H2: There is a positive and significant impact of individual characteristic on non-managerial employee performance in hotel industry in Matale district

H3: There is a positive and significant impact of trainers on non-managerial employee performance in hotel industry in Matale district

H4: There is a positive and significant impact of work environment on non-managerial employee performance in hotel industry in Matale district 


\section{METHODOLOGY}

The objective is to establish the impact of independent variables (training) on the dependent variable (employee performance). Therefore, the type of this study is regression and correlational rather than causal study. This study is conducted within the natural environment in the hotel sector under minimal interference within a non-contrived setting. Quantitative techniques were used for data collection and analysis. Data was collected by non-managerial employees in hotels in Matale district were considered as single respondent. Hence the unit of analysis of the study is individual. Population of the study were concerned with the non-managerial employees in the selected three hotels in Matale district. There were totally 311 non managerial employees in the selected hotel. Thus all 311 non managerial employees were the population of the study. Selected employees perform in different departments. Proportionate stratified random sampling method was used for selecting sample. Considering the time and convenience of the research requirements, sample size selected as 154 . In here $50 \%$ of employees were in each level, included in this sample. Data was collected in using a structured questionnaire which consisted of 50 questions to identify the impact of independent variables on dependent variable. Descriptive statistic, correlation analysis and regression analysis were used to analyzed the data. And also, researcher used Cronbach's Alpha for test reliability of questionnaires. Cronbach's alpha is a reliability coefficient that point out how well the items in set are positively correlated to one another. (Sekaran, 2010).

\section{Conceptual Framework}

The figure 3:1 shown below, described relationship between training and employee performance. Based on the empirical evidences mentioned earlier the following conceptual frame work has developed. The purpose of the study is to examine the impact of training on employees' performance. Thus training considered as the independent variable and employee performance is the dependent variable.

Figure: 3:1 Conceptual Framework

Independent Variable $\quad$ Dependent Variable

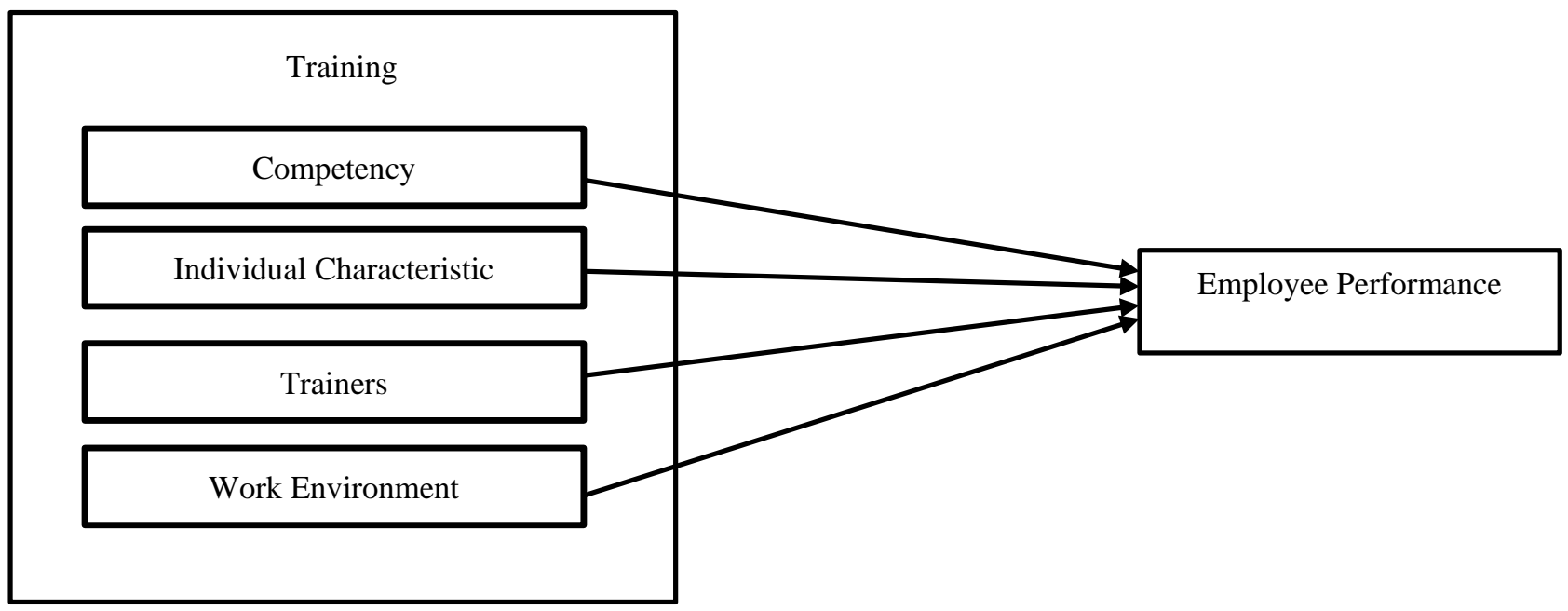

Source: Developed by Researcher

\section{RESULTS AND DISCUSSION}

\subsection{Reliability Analysis}

Internal consistency of research variables is represented by the reliability test. Consistency explained how well the items measuring a concept hang together as a set (Sekaran, 2010) The value of the Cronbach's alpha was used to analyze the reliability of the instruments.

Table 4 1: Results of Reliability Analysis 


\begin{tabular}{|l|c|c|}
\hline Variable & No: of Items & Cronbach's Alpha \\
\hline Competency & 17 & 0.870 \\
\hline Individual characteristics & 7 & 0.755 \\
\hline Trainers & 6 & 0.763 \\
\hline Work Environment & 5 & 0.824 \\
\hline Employee Performance & 15 & 0.904 \\
\hline
\end{tabular}

Source: Survey Data (2019)

Generally accepted minimum standard value for the for internal consistency was 0.7 . According to the results mentioned by above table 4.1 competency has 0.870 Cronbach alpha value and 0.755 Value for the individual characteristics. 0.763 Cronbach value for the trainers and for work environment 0.824 Cronbach alpha value and for Employee performance 0.904 Cronbach value. Thus all the Cronbach value for the variables used for the study is greater than 0.7 It revealed that each item was positively correlated with one another and the internal consistency reliability was satisfactory.

\subsection{Demographic Profile of the Respondents}

Table 4 2: Demographic Profile of the Respondents

\begin{tabular}{|l|c|l|c|}
\hline \multicolumn{1}{|c|}{ Gender } & $\mathbf{\%}$ & \multicolumn{1}{c|}{ Department } & \% \\
\hline Male & 77 & Front Office & 15 \\
\hline Female & 23 & Housekeeping & 27 \\
\hline \multicolumn{1}{|c|}{ Age } & $\mathbf{1 0 0}$ & Food and Beverage & 36 \\
\hline Less than 30 & $\mathbf{\%}$ & Account & 10 \\
\hline Between 30-50 & 47 & Maintenance & 12 \\
\hline More than 50 & 43 & & $\mathbf{1 0 0}$ \\
\hline & 10 & \multicolumn{1}{c|}{ Education Level } & $\mathbf{\%}$ \\
\hline Experience (Years) & $\mathbf{1 0 0}$ & Up to O/L & 19 \\
\hline Less than 10 & $\mathbf{\%}$ & Passed O/L & 26 \\
\hline Between 10-20 & 63 & Passed A/L & 32 \\
\hline More than 20 & 32 & Diploma & 17 \\
\hline & 5 & Other & 6 \\
\hline
\end{tabular}

Source: Survey Data (2019)

\subsection{Descriptive Analysis for Research Variables}

Table 43 Descriptive Statistics

\begin{tabular}{|l|c|c|}
\hline \multicolumn{1}{|c|}{ Variables } & Mean & $\begin{array}{c}\text { Standard } \\
\text { Deviation }\end{array}$ \\
\hline Competency & 3.8079 & .40696 \\
\hline Individual Characteristics (IC) & 3.7462 & .44503 \\
\hline Trainers & 3.4822 & .47251 \\
\hline Work Environment (WE) & 3.6466 & .60857 \\
\hline Employee Performance (EP) & 3.7819 & .48697 \\
\hline
\end{tabular}

Source: Survey Data (2019)

Mean value for overall employee performance indicated 3.7819 and value of Standard deviation of the study for the selected variables reported less than 1 which indicates small deviations in responses given by respondents. Mean and SD was used to determine the extent of spread of the data. 


\subsection{Correlation Analysis}

In this section examines the relationship between independent variables and dependent variable in order to test the hypothesis of the research. Therefore, Pearson correlation analysis was used and its results are represented in table 4.4

Table 4.4: Result of Pearson's Correlation Analysis

\begin{tabular}{|l|l|c|}
\hline \multicolumn{1}{|c|}{ Variable } & \multicolumn{1}{|c|}{ Correlation } & $\begin{array}{c}\text { Employee } \\
\text { Performance }\end{array}$ \\
\hline Competency & Pearson Correlation & $.542^{* *}$ \\
& Sig. (1-tailed) & .000 \\
\hline Individual Characteristics & Pearson Correlation & $.479^{* *}$ \\
& Sig. (1-tailed) & .000 \\
\hline Trainers & Pearson Correlation & $.306^{* *}$ \\
& Sig. (1-tailed) & .001 \\
\hline Work Environment & Pearson Correlation & $.409^{* *}$ \\
& Sig. (1-tailed) & .000 \\
\hline Employee Performance & Pearson Correlation & 1 \\
& Sig. (1-tailed) & \\
\hline
\end{tabular}

Source: Survey Data (2019)

**. Correlation is significant at the 0.01 level (1-tailed).

*. Correlation is significant at the 0.05 level (1-tailed)

As shown in Table 4.4 correlation coefficient for competency is 0.542 , IC is 0.479 , Trainers is 0.306 and WE is 0.409 and all variables were significant at $0.01(\mathrm{p}<0.01)$. Accordingly, it could be concluded that competency, IC, Trainers and WE has significant positive relationship between EP. This result support the hypothesis of the study.

\subsection{Result of Regression Analysis}

Table 4.5 Result of Regression Analysis

\begin{tabular}{|c|c|c|c|c|c|}
\hline \multicolumn{3}{|c|}{ R Square : 0.393} & \multirow{3}{*}{$\begin{array}{l}\mathrm{F}=15.893 \\
\begin{array}{l}\text { Standardized } \\
\text { Coefficients }\end{array}\end{array}$} & \multicolumn{2}{|l|}{ Sig. 0.000} \\
\hline \multirow{2}{*}{ Model } & \multicolumn{2}{|c|}{ Unstandardized Coefficients } & & $\mathrm{t}$ & \\
\hline & $\beta$ & Std. Error & & & \\
\hline 1 (constant) & 1.312 & & & & .001 \\
\hline Competency & .649 & .100 & .542 & 6.483 & .000 \\
\hline IC & .524 & .096 & .479 & 5.481 & .000 \\
\hline Trainers & .316 & .098 & .306 & 3.234 & .002 \\
\hline WE & .327 & .073 & .409 & 4.506 & .000 \\
\hline
\end{tabular}

Source: Survey Data (2019)

Dependent Variable: Employee Performance 
When considering table 4.5the unstandardized coefficients for four variables it indicated that competency, IC, Trainers and WE are significantly influence by employee performance. Furthermore, it explained that competency $(\beta=.649 ; p=0.000)$, IC $(\beta=.524 ; p=$ $0.000)$. , trainers $B=0.316 ; \mathrm{p}=0.002)$. and $\mathrm{WE}(\beta=0 . .327 ; \mathrm{p}=.000)$ had a significant positive impact on employee performance. Regression model was fitted at sig value of $0.000(\mathrm{p}<0.05) \mathrm{R}^{2}$ value as 0.393 . It means model was strongly fitted to the data and $39 \%$ variance of employee performance was explained by those four independent variables (competency, individual characteristic, trainers and work environment)

These results are similar to the findings of previous researches on impact of training on employee performance (Raza, 2015; Hassan, 2015; Gitongu , 2016; Desa, 2011; Salah, 2016; Monosomy, 2013).

According to the results all the hypothesis developed for the study was accepted based on the results value of the simple regression and person's correlation analysis.

\section{CONCLUSION AND RECOMMENDATION}

This study investigated the impact of training on non-managerial employee performance in hotel industry. All four independent variables used for the study competency, individual characteristic, trainers and work environment had significant positive impact on employee performance. According to the findings all the hypotheses in the study were supported. This research also served as a guideline for all the researchers interested in studying this area. The findings of this study help to the hotels in planning and developing the strategies to enhance the employee performance. Recently the newly trend in Sri Lanka is building entrepreneurs in tourism industry. Thus the persons who are planning to newly enter to the hotel industry also will be important the findings of the study in order to enhance the employee performance through success training program and ultimately organizational performance. The output of regression analysis of the study concluded that positive impact of training on employee performance and 39\% variance of employee performance was explained by four independent variables used for the study. (competency, individual characteristic, trainers and work environment). Among them competency has strong positive impact on employee performance. Thus, organizations must pay considerable attention to enhancing the employees' competencies in order to enhance the employee performance and identifying that what are the major skills and knowledge need to be improve and based on that align the training sessions. In order to develop the employee competencies employers must be lined with the new technology to gain the competitive advantage. Thus the organizations need to focusing on merging the training program with up to dated technology in order to deliver better training for achieving higher level of employee performance. Also results revealed that work environment also has positive impact on employee performance. providing proper work environment for the training helped to achieved success training program and ultimately greater employee performance. For the research social support (Supervisory support and peer support) were considered under work environment. Most of the respondents strongly agreed that positive supervisory and peer support helped for achieved success training. Thus providing feedback for the employees are one of major factor that can be satisfied the trainees. Also having strong social relationship with employees caused to increase the level of attending of the trainees for the training programs. providing feedback after the training is important in order to aware about the areas that employees need to be improved. Thus employers need to focus on building upon proper relationship between supervisor and subordinate, supervisory feedback and discussion in order to satisfy the employees regarding the training program and to have better attending and success for the training sessions.

This study had provided only a small portion of idea to identify the impact of training on non-managerial employee performance in hotel industry in Matale district. Hence, following suggestions are important for future research. For the study it had investigated the impact of training on employee performance in hotel industry. Hence it suggests for future researches to Expand the study into other sectors by examine the impact of training on employee performance in other private and public industries. Selected sample size for the research is small. It has elected 154 non managerial employees as the sample size. Thus it suggests for the future studies should be undertaken at the higher level with larger sample size than this study. For this study it had considered selected four dimensions only. According to the results disused earlier revealed that only $39 \%$ variance impact has for the training. Thus there are many dimensions that has not covered which are included for remaining $61 \%$. Thus it suggests for the future research to select more dimension

\section{REFERENCES}

[1] Abbas, Q. Y. (2009). Abbas, Q., \& Yaqoob, S. (2009). Effect of Laedreship Developmet on Empoyee Performance. . Pakistan Economic and Social Review, , 47(2), 269-292.

[2] Adesola, A. B. (2017). The Impact Of Training And Development On Employee Performance In Radisson Blu Anchorage Hotel. Redeemers University, Osun State

[3] Afsana, J., Afrin , F., \& Tarannum, T. (2016). Effect of training on employee performance: an empirical study on telecommunication industry in Bangladesh. Journal of Business and Technology, 10(2), 67-80.

[4] Aguinis, H. (2006). Performance management. Denver, Colorado, USA: Prentice Hall.

[5] Ahuja, K. (2006). Personnel management (3rd ed ed.). New Delhi: Kalyani Publishers.

[6] Ali, H. (2011). A comparison of cooperative learning and traditional lecture methods in the project management department of a tertiary level institution in Trinidad and Tobago. The Caribbean Teaching Scholar, 1(1),49-64.

[7] Allworth, E., \& Hesketh, B. (1997). Capturing Change Related and Contextually Relevent Future Performance. Select Acess.

[8] Alsaleem, S. A. (2013). Influence of trainees' characteristics and organizational climate on training transfer. Masters Theses. Retrieved from http://commons.lib.jmu.edu/master201019 
[9] Ameeq, A. U., \& Hanif, F. (2013). Impact of Training on Employee's Development and Performance in Hotel Industry of Lahore, Pakistan. Journal of Business Studies Quarterly.

[10] Ampomah, P. (2016). The Effect of Training and Development on Employee Performance in a Private Tertiary Institution in Ghana" (Case Study: Pentecost University College (Puc) - Ghana). . Asian Journal of Social Sciences and Management Studies, 3(1),29-33.

[11] Antle , B., Barbee , A., Sullivan, D., \& Christensen, D. (2009). 2009, _The effects of training reinforcement on training transfer child welfare` Child Welfare, Vol 88, .

[12] Arvey , R., \& Mussio, S. (1973). A test of expectancy theory in a field setting using female clerical employee. Journal of Vocat Behavior.

[13] Baldwin, T., \& Ford, J. (1988). Transfer of training, A review and directions for future. Personnel Psychology, 4,63-105.

[14] Bergenhenegouwen, G., Horn, H., \& Mooijman, E. (1996). Competence development — a challenge for HRM professionals: core competences of organizations as guidelines for the development of employees. Journal of European Industrial Training, 20(9).

[15] Borman, W., \& Motowidlo, S. (1993). Expanding the criterion domain to include elements of contextual performance. San Francisco, CA: Jossey Bass.

[16] Burke, L., \& Hutchins, H. (2007). Training Transfer: An Integrative Literature Review. Human Resource Development Review, 6 (3), $263-296$.

[17] Burke, L. A., \& Hutchins, H. M. (2008). A Study of Best Practices in Training Transfer and Proposed Model of Transfer. Human Resource Development Quarterly.

[18] Bushiri, C. P. (2014). The Impact Of Working Environment On Employees' Performance: The Case Of Institute Of Finance Management In Dar Es Salaam Region. Management Of The Open University, Tanzania.

[19] Campbell, J. (1994). Alternative Model of Job Performance and their implications for selection classification. England: Lawrence Erlbaum Associate Inc.

[20] Chapmann , J., \& Loveall, G. (2006). The competency model of hospitality service: why it doesn't deliver. International Journal of Contemporary Hospitality Management, $8(1), 78-88$

[21] Chiaburu, D., \& Lindsay, D. (2010). Can do or will do? The importance of self-efficacy. Human Resource Development, 11(2).

[22] Cifci, O. S. (2014). Transfer System Factors On Training Transfer With Regard To Trainee Characteristic And Contextual Variable - A Case Study Of Central Bank Of The Rebublic Of Turkey. Graduate School Of Social Sciences Graduate School .

[23] Coates, D. (2004). People skills training: Are you getting a return on investment? Performance Support System.

[24] Coetsee, W., Eiselen, R., \& Basson, J. (2006). Validation Of The Learning Transfer System Inventory In The South African Context . Sa Journal Of Industrial Psychology, 46-55.

[25] Croskey, M., \& Holdrige, J. (1974). An instrument for measuring the source credobility of basic speech communication instructor. Communication Education, 23(1),26-33.

[26] Daily Mirror. (2017, 11 18). Labour Shortage in Key sectors.

[27] Daily Mirror. (2018, 11 19). Tourism Industry Sees Slowdown in Booking during Key winter Season.

[28] Daily News. (2010, 02 27). Developing Tourism inSri Lanka.

[29] DailyMirror. (2015). How Important is Tourism for Sri Lankas Development. Wijeya News Papers.

[30] Driskell, J. E. (2011). Effectiveness of Deception Detection Training: A MetaAnalysis", Psychology, Crime \& Law. 1-19.

[31] Duggan, K. (2017). Performance Management. . Annual review fade away.

[32] Dysvik, A., \& Kuvaas, , B. (2008). the relationship between percieved training oppertunities, work motivation and emplyee outcomes. ,. International journal of training and development, 12(3),138-157.

[33] Edwards, J. S. (2013). Factors affecting training transfer in supervisors and hourly employees in a manufacturing organization. Southern Cross University. Lismore, NSW. : ePublications@SCU.

[34] Fluegge, E. (2009). Who put the fun infunctional?Funatwork anditseffectsonjob performanc. Hum Soc Sct: Dissertation Abstr Int .

[35] Gitongu , M. K., Kingi, W., \& Uzel , J. M. (2016). Determinants of Employees' Performance of State Parastatals in Kenya: A Case of Kenya Ports Authority . International Journal of Humanities and Social Science.

[36] Govindappa, D., \& MANJULA, V. (20017). The impact of training dimensions on employee's work performance: An analytical study in Karnataka soaps and detergents limited in Bengaluru. International Journal of Academic Research and Development, 351-353.

[37] Griffin, A., \& Mark, A. (2007). Perciption of safety performace. Jouranal of Occupational Health Psychology, 5(3) 347-358.

[38] Habib , A., \& Hossain, S. (2016). Assessing The Effect Of Training On Employees' Performance In Nigeria Hotel Industry (A Case Study Of Sheraton Hotel And Resorts Lagos). Singaporean Journal Of Business Economics, 5(4).

[39] Habib , Ahsan; Hossain, Shahadat ; Essien. (2016). Assessing The Effect Of Training On Employees' Performance In Nigeria Hotel Industry. Singaporean Journal Of Business Economics, And Management Studies, 5(4).

[40] Hailesilasie, G. (2009). Determinants of public employees' performance: evidence from Ethiopian public organizations. International Journal of Productivity and Performance Management, 58 (3), 238-253.

[41] Hameed, A., \& Waheed, A. (2011). Employee development and its affect on employee performance: A conceptual framework. International Journal of Business and Social Science, 2 (13), 224-229.

[42] Harris, T., Hutchins, H., \& Chiaburu, D. (2014). Do trainer style and leaner orientation predict training outcomes? Journal of Work Place Learning, 26(5).

[43] Hassan, I. B., Mugambi , F., \& Waiganjo , E. (2015). Effect of Training on the Performance of the Star Rated Hotels in Kenya. International Journal of Business and Commerce, 53-64.

[44] Hijr, H., \& Haleem, A. (2017). Study the Factors That Influence Employees Performance in the Steel Factory, Saudi Arabia. Proceedings of the 2017International Conference on Industrial Engineering and Operations Management.

[45] Holladay, C., \& Quinones. (2008). The influence of training focus and trainer characteristics on diversity training effectiveness. academy of Management and Learning and Education, 7(3),343-354.

[46] Holton, E., \& Baldwin, T. (2003). San Francisco, CA: John Wiley \& Sons.

[47] Holton, E., Bates, R., Bookter, A., \& Yamkovenko, V. (2007). Convergent and divergent validity of the learning transfer system inventory. Human Resource, 18(3).

[48] Hutchin, H. (2009). In the Trainer's Voice. Performance improvement Quartely, 22(1),69-93.

[49] Imran,, R., Fatima, A., Zaheer, A., Yousaf, I., \& Batool, I. (2012). How to Boost Employee Performance: Investigating the Influence of Transformational Leadership and Work Environment in a Pakistani Perspective. Middle-East Journal of Scientific Research, 1455-1462.

[50] Jakfar, A. A. (2014). Influence of Individual Characteristics, Organizational Culture and Work Motivation to Satisfaction and Performance of Hand-Rolled Cigarette Workers at the Cigarette Industry in Madura. International Journal of Science and Research, 3(1). 
[51] Jiambalvo, J. (1979). Performance evaluation and directed job effort: model development and analysis. CPA firm .

[52] Johnson, E., \& Meade, A. (2010). A multi - level investigation of overall job performance ratings. Annual Meeting of the society for Industrial and Organizational Psychology. Atlanta.

[53] Kalkavan, S., \& Katrinli, A. (2014). The effects of managerial coaching behaviors on the employees perception of job satisfaction, organizational commitment, and job performance: Case Study On Insurance Industry in Turkey. Procedia - Social and Behavioral. Turkey.

[54] Kappagoda, S. U. (2018). Self-Efficacy, Task Performance and Contextual Performance: A Sri Lankan Experience . Journal of Human Resource and Sustainability Studies, 157-166.

[55] Kaur, A., Shriram, R., \& Ravichandran, P. (2011). A Framework for Online Teaching and Learning. Filigree.

[56] Kay, C., \& Russette, J. (2000). Hospitality-management competencies. Quarterly,. Cornell Hotel and Restaurant Administrative, 41 (2), 52-63.

[57] Kim, Y., Kim, S. S., Seo, J., \& Hyun , J. (2011). Hotel Employees' Competencies and Qualifications Required According to Hotel Divisions. Journal of Tourism, Hospitality \& Culinary Arts.

[58] Kolibacova, G. (2014). The Relationship Between Competency And Performance. Acta Universitatis Agriculturae Et Silviculturae Mendelianae Brunensis.

[59] Koopmans, L., Bernaard, C. M., Hildebrand, V. H., Schaufeli, W. B., Vet, H. C., \& Beek, A. J. (2011). Conceptual Frameworks of Individual Work Performance A Systematic Review. Journal of occupational and environmenta, 53(8).

[60] Kum, F. D., Cowden, R., \& Karodia, A. M. (2014). The Impact Of Training And Development On Employee Performance: A Case Study Of Escon Consulting. Singaporean Journal Of Business Econommics, And Management Studies, 3(3),24.

[61] Lankeshwara, P. (2016). A study on the impact of workplace environment on employee's performance: with reference to the Brandix Intimate Apparel - Awissawella International Journal of Multidisciplinary Studies, 3(1),47-57.

[62] Lim, D., \& Morris, M. (2006). Influence of Trainee Characteristics, Instructional Strategies, and Organizational Climate on Perceived Learning and Training. Wiley Periodicals.

[63] Lipsey, R. G. (1989). Introduction to positive economics (7th ed ed.). London: Weindnfeld and Nicholson.

[64] Malik, I., Ahmad, A., Gomez, S. F., \& Ali, M. (2011). A study of work environment and employees' performance in Pakistan . African Journal of Business Management, 13227-13232.

[65] Margaret, G. K., William , K., \& Uzel, J. M. (2016). Determinants of Employees' Performance of State Parastatals in Kenya: A Case of Kenya Ports Authority International Journal of Humanities and Social Science , 6(10).

[66] Mathieu, J. E. (1993). Factors That Influence Training Effectiveness: A Conceptual Model And Longitudinal Analysis. Pennsylvania State University, Orlando.

[67] Motlokoa, M. E., Sekantsi , L. P., \& Monyoloc, R. P. (2018). The Impact of Training on Employees' Performance: The Case of Banking Sector in Lesotho . International Journal of Human Resource Studies .

[68] Mubarok, E. S., \& Putra, H. (2018). The Influence of Training, Competence, and Motivation on Employees Performance of Workers Social Security Agency in Banten Province, Indonesia. Journal of Economics and Sustainable Development .

[69] Murphy, K. (1989). Dimensions of job performance. . New York: Praeger.

[70] Musriha, H. (2016). The Impact of Individual Characteristics and Organization Culture on Performance and Career Development of Employees Case studies Five Star Hotel in Surabaya Indonesia. IOSR Journal of Business and Management , 4(3),21-27.

[71] NANZUSHI, C. (2015). THE EFFECT OF WORKPLACE ENVIRONMENT ON EMPLOYEE. University Of Nairobi, Nairobi.

[72] Nassazi, A. (2013). Effects Of Training On Employee Performance. Evidence From Uganda. International Business.

[73] Neo, R. (2010). Employee Training and Development. New York: McGraw Hill.

[74] Omari , K. A., \& Okasheh, H. (2017). The Influence of Work Environment on Job Performance: A Case Study of Engineering Company in Jordan . International Journal of Applied Engineering Research, 15544-15550 .

[75] Omran, A. (2016). Examining the Effect of Training Strategies on Employees' Performance in the Libyan Construction Industry. Journal Of Engineering Management And Competitiveness (JEMC) VOL, 99-110.

[76] Otuko, A. H., Chege, K., \& Douglas, M. (2013). Effect Of Training Dimensions On Employee's Work Performance: A Case Of Mumias Sugar Company In Kakamega County . International Journal of Business and Management Invention, 138-149.

[77] Pine, L. S., Desa, N. M., \& Asaari, M. H. (2016). Big Five Factors and Employees' Voice Behavior among Employees in Small-Medium Enterprise in Penang . Review of European Studies, 8(3).

[78] Prasetya , A., \& Kato , M. (2011). The Effect of Financial and Non Financial Compensation to the Employee Performance. Indonesia.: Yogyakarta.

[79] Profijt, J. G. (2015). The influence of the work environment on training transfer. Universitiet Twente.

[80] Pulakos, E., Arad , S., Donovan, M., \& Plamondon, K. (2000). Adaptabilityintheworkplace: development of a taxonomy of adaptive performance. J Appl Psychol, 299-334.

[81] Punia, B., \& Kant, S. (2013). A Review of Factors Affecting Training Effectiveness Managerial Implications and Future Research Directions. International Journal of Advanced Research in Management and Social Sciences.

[82] Raza, S. N., Shahbodin, F., \& Hussinb, H. (2015). Online Collaborative Learning Elements To Propose An Online Project Based Collaborative Learning Model . Jurnal Teknologi

[83] Rehman, A. U., Ullah, M. I., \& Haq, M. A.-u. (2015). The Influence of Individual Characteristics on Organization Performance and Job Satisfaction . International Journal of Scientific and Research Publications, 5(2).

[84] Salah, M. R. (2016). The Impact of Training and Development on Employees Performance and Productivity. International Journal of Management Sciences and Business Research, 5(7).

[85] Sandamali, J., Padmasiri, D., Mahalekamge, W., \& Mendis, M. (2018). The Relationship between Training and Development and Employee Performance of Executive level Employees in Apperal Organizations. Interntional Invention of Scientific Journal, 2(1).

[86] Sandamali, J., Padmasiri, M. D., Mahalekamge, W., \& Mendis, M. (2018). The Relationship Between Training and Development and Employee Performance of Executive Level Employees in Apperal Organizations. International Invention of Scientific Journal.

[87] Sanyal, S. (2018). Impact of Training and Development on the Performance of Employees - A Comparative Study on Select Banks in Sultanate of Oman . International Journal of Scientific Research and Management , 6(3),191-198.

[88] Sauer, K. (2012). The impact of student intrest and instructor effectiveness on student performance. Fisher Digital Publication.

[89] Sekaran, U. (2010). Research Methods for Business. New York: Jhon Wiely \& sons . 
[90] Shafiq, S., \& Hamza, S. M. (2017). THE EFFECT OF TRAINING AND DEVELOPMENT ON EMPLOYEE PERFORMANCE IN PRIVATE COMPANY, MALAYSIA. International Journal of Education, 2(2),42-56.

[91] Sharif, M. Y., \& Bhuiyan, A. B. (2015). The Factors That Affect The Effectiveness Of Training: A Study At Silterra Malaysia Sdn. Bhd., A Semiconductor Company In Malaysia. International Journal of Management Studies, 33-46.

[92] Sinclair, R., \& Tucker, J. (2006). Integrated model of individual differences in soldier performance under stress. Castro CA: Westport.

[93] Spears, W. (2014). Factors affecting training effectiveness in synchronous, dispersed virtual environments. Naval Postgraduate School, Monterey, California. Retrieved from http://hdl.handle.net/10945/42730

[94] Stoner, J. A. (1996). Management, 6th ed., : . Australia: Pearson Education.

[95] Switzer, K., Nagy , M., \& Mullins, M. (2005). The Influence of Training Reputation,. Applied H.R.M. Research, 10,21-34.

[96] SYAIFUDDIN. (2017). Analysis of the Effect of Individual Characteristics, Employees' Competency and Organizational Climate on Job Satisfaction and Employees' Performance at a State-Owned Trading Company in Indonesia. Expert Journal of Business and Management, 5(2),83-90.

[97] Tahir , N., Yousafzai, I. K., Jan , S., \& Hashim, M. (2014). The Impact of Training and Development on Employees Performance and Productivity A case study of United Bank Limited Peshawar City, KPK, Pakistan . International Journal of Academic Research in Business and Social Sciences .

[98] Tanveer, A. (2015). Impact Of Training Development On Employees Performance In Banks. European Journal of Training and Development Studies , $3(1), 22-44$.

[99] Tonhauser, C., \& Buker, L. (2016). Determinants of Transfer of Training: A Comprehensive Literature Review. International Journal for Research in Vocational Education and Training (IJRVET) , 127-165.

[100]Tracey, J. B., Hinkin, T. R., Tannenbaum, S., \& Mathieu, J. E. (2001). The Influence of Individual Characteristics and the Work Environment on Varying Levels of Training Outcomes. Cornell University, School of Hotel Administration . Retrieved from http://scholarship.sha.cornell.edu/articles

[101] Viswesvaran, C. (2005). Is there a general factor in ratings of job performance? J Appl Psychol.

[102]Waris, A. P. (2015). Effect of Training, Competence and Discipline on Employee Performance in Company . Procedia - Social and Behavioral Sciences , 12401251.

[103] Yang, J. H., Fan, S. C., \& Huang, C. Y. (2017). The Mediating Role of Competency on the Relationship between Training and Task Performance: Applied Study in Pharmacists . International Journal of Business Administration .

[104] Yaqoot, E. S., Noor, W. h., \& Isa, M. F. (2017). Factors Influencing Training Effectiveness: Evidence from Public Sector in Bahrain . Acta Universitstis Danubius.

[105]Zaim, H., Yaşar, M. F., \& Unal, O. F. (2013 ). Analyzing The Effects Of Individual Competencies On Performance: A Field Study In Services Industries In TurkeY . Journal of Global Strategic Management .

\section{AUTHORS}

First Author - G.M.D.C.Disanayaka, Under Graduate, Rajarata University of Sri Lanka, gmdinushi@gmail.com

Second Author - W.W.A.N.Sujeewa, Senior Lecturer, Rajarata University of Sri Lanka, nasutwin@ gmail.com

Correspondence Author - G.M.D.C.Disanayaka, gmdinushi@ gmail.com, +94770844605/+94717744605 